\title{
Tumores sincrónicos de glándula salivar. A propósito de dos casos
}

\author{
Synchronous salivary gland tumors with regard to two cases
}

\author{
J. Azúa-Romeo', E. Saura Fillat², T. Usón Bouthelier², M. Tovar Lázaro³, J. Azúa Blanco ${ }^{4}$
}

Resumen: Presentamos dos casos de pacientes con tumores sincrónicos de glándula salivar. El primero se refiere a dos tumores benignos en la misma glándula parótida, mientras que el segundo caso se trata de una lesión maligna y otra benigna en glándulas parótida y submaxilar ipsilaterales. Los dobles tumores sincrónicos homolaterales de glándula salivar son muy infrecuentes, suponiendo menos del $0,3 \%$ de los tumores de esta localización. La bibliografía revisada refiere 42 casos entre los que sólo 9 presentan un tumor maligno y otro benigno.

El diagnóstico citológico preoperatorio, junto con una exhaustiva inspección macroscópica intraoperatoria son las claves para detectar los segundos tumores, habitualmente más pequeños y no detectados en estudios previos, y así adecuar el procedimiento terapéutico.

Palabras clave: Sincrónico; Glándula salivar; Tumor; Citología.

Recibido: 13 de septiembre 2004

Aceptado: 11 de noviembre 2004

\begin{abstract}
We present two new cases of synchronous tumors of the salivary gland. The first one refers to two benign tumors in the same parotid gland, while second one shows a benign lesion and a malignant tumor in two ipsilateral salivary glands.

The appearance of synchronous multiple unilateral parotid tumors of different histologic types is extremely rare, accounting for less than 0.3\%; this is usually a Warthin's Tumor associated to other tumors. The current literature has been reviewed and 42 cases have been found entailing two different parotid tumors coexisting. Of these 11 referred to adenolymphoma associated with pleomorphic adenoma.

Preoperative cytological diagnosis, as well as an exhaustive intraoperative inspection are the clues to discover nonidentified second tumors.
\end{abstract}

Key words: Synchronous; Salivary gland; Tumor; Cytology.

1 Patólogo. Instituto Aragonés de Ciencias de la Salud.

Profesor Facultad de Medicina. Zaragoza, España.

2 Servicio de Cirugía Oral y Maxilofacial. Hospital Universitario Miguel Servet. Zaragoza, España.

3 Atención Primaria. Zaragoza, España

4 Patólogo. Profesor Facultad de Medicina. Zaragoza, España

\section{Correspondencia:}

Dr. Javier Azúa-Romeo

So Anatomía Patológica (Banco de Tumores)

Hospital Universitario Miguel Servet

po Isabel la Católica 1 y 3

50009 Zaragoza, España. 


\section{Introducción}

La aparición de tumores histológicamente diferentes en glándulas salivares ipsilaterales, es extremadamente rara, con una frecuencia inferior al $0,3 \%$ de todos los tumores de glándula salivar. ${ }^{1}$ La bibliografía actual muestra tan solo 42 casos, de los que únicamente 9 se refieren a la coexistencia de un tumor benigno con una lesión maligna. ${ }^{2-4}$

Habitualmente se trata de un tumor de Warthin asociado a otro tipo de lesión.

Nosotros presentamos dos casos real-

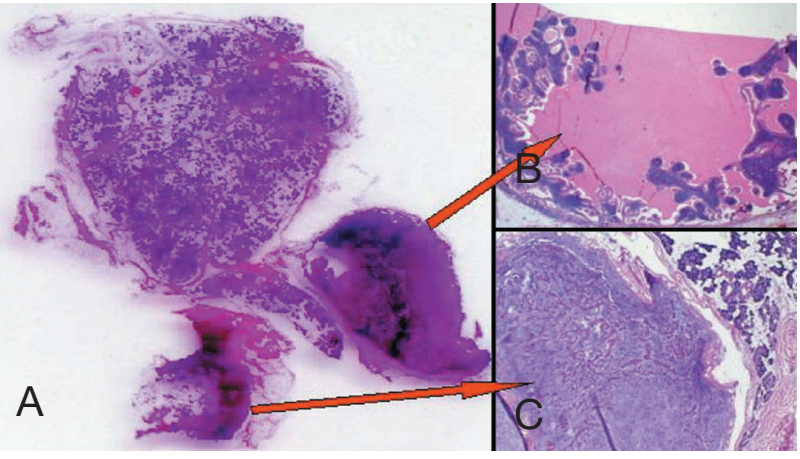

Figura 1. A) Imagen macro-microscópica, identificando los dos tumores. B) Tumor de Warthin. C) Adenoma pleomorfo.

Figure 1. A) Macro-microscopical image, identifying both tumors. B) Warthin's tumor. C) Pleomorphic adenoma.
Introduction

The appearance of two ipsilateral salivary gland tumors of different histologic types is extremely rare making up less than $0.3 \%$ of all salivary gland tumors. ${ }^{1}$ The current literature describes only 42 cases, of which only 9 refer to the coexistence of a benign tumor with a malignant one. ${ }^{2}$

This is normally a Warthin's tumor associated with another type of lesion. We mente excepcionales, en los que se asocian un tumor de Warthin con un adenoma pleomorfo en la misma glándula parótida, y un carcinoma de células acinares con un oncocitoma en parótida y submaxilar izquierdas respectivamente. El abordaje diagnóstico inicial se suele realizar a través de punción aspiración con aguja fina (PAAF), obteniendo una alta sensibilidad y especificidad, lo que permite establecer un abordaje terapéutico ajustado. ${ }^{5}$

\section{Casos clínicos}

\section{Caso 1}

Paciente de 44 años remitida por el médico de cabecera al Servicio de Cirugía Oral y Maxilofacial por presentar una tumoración parotídea, que a la palpación parecía constar de un único nódulo. Con la sospecha de tumoración benigna se realizó punción aspiración con aguja fina de 23-G en el Servicio de Anatomía Patológica, fijando el material obtenido, de manera inmediata, en alcohol de $95 \%$ y reservando uno de los aspirados para secado al aire. Las muestras fijadas en alcohol se tiñeron siguiendo la técnica de Papanicolaou, mientras que los secados al aire se colorean con la técnica de DiffQuick.

Citológicamente se observa una lesión compuesta de células epiteliales y ductales sobre un fondo basofílico fibrilar y mixomatoso, además se aprecia un material condroide y fragmentos de estroma eosinófilo fibrilar. El diagnóstico citológico fue de adenoma pleomorfo (AP) por lo que se realizó parotidectomía total con preservación del nervio facial.

La pieza quirúrgica se incluyó en formaldehído al 10\% observando macroscópicamente un tumor de $2 \times 2 \mathrm{~cm}$, de consistencia blando-elástica y coloración blanquecina, parcialmente encapsulado, así como una lesión nodular polilobulada de $1,5 \mathrm{~cm}$ de apariencia linfoide, separada del tumor principal por un fino cordón estromal (Fig. 1A). Tras la fijación se secciona la pieza en su totalidad y se procesa de manera rutinaria para obtener los bloques de parafina. La tinción empleada para la observación microscópica es hematoxilina-eosina clásica.

El estudio microscópico muestra un tumor principal bien circunscrito, rodeado por una pseudocápsula conectiva, compuesto present two cases that are quite exceptional. One cases documents the association of a Warthin's tumor with a pleomorphic adenoma in the same parotid gland, and the other documents the association of an acinic cell carcinoma with an oncocytoma of the parotid and submaxillary glands on the left side respectively. The initial diagnostic approach is usually made by means of fine needle aspiration puncture (FNA), through which high sensibility and specificity is obtained, allowing an appropriate therapeutic approach. ${ }^{5}$

\section{Case Report}

Case 1

A 44 year-old patient was sent by her General Practitioner to the Oral and Maxillofacial Unit due to the appearance of a tumor-like mass in the parotid gland, which to palpation appeared uninodular. A benign tumor was suspected and fine needle aspiration was carried out with a $23 \mathrm{G}$ needle in the Pathological Anatomy Unit. The material obtained was fixed immediately in $95 \%$ alcohol while one aspirate was reserved and air-dried. The samples that were fixed in alcohol were stained by the Papanicolaou technique, while those that were air-dried were stained using the DiffQuick technique.

Cytologically a lesion was observed consisting of ductal epithelial cells with a basophilic fibrillar and myxomatous background. In addition chondroid material and fragments of fibrillar eosinophilic stroma could be appreciated. The cytological diagnosis was of pleomorphic adenoma (PA) and, as a result, a total parotidectomy was carried out while preserving the facial nerve.

The surgical specimen was fixed in 10\% formaldehyde solution and a tumor that was $2 \times 2 \mathrm{~cm}$ was observed macroscopically. It was whitish in color with a soft elastic consistency, and it was partially encapsulated. A polylobulated nodular lesion measuring $1.5 \mathrm{~cm}$, lymphoid in appearance and separated from the main tumor by a fine strand of stroma (Fig. 1A) was also observed. Following fixation, the spec- 
por una población celular bifásica de epitelio glandular y células mioepiteliales rodeadas por un material fibrilar mixoide, por lo que se confirma el diagnóstico de adenoma pleomorfo (Fig. 1C). Los otros nódulos eran ganglios linfáticos, pero apareció una nueva lesión, de pequeña talla, muy cercana al tumor mixto, de apariencia quística y papilar, constituida por una doble hilera de células oncocíticas rodeando los espacios quísticos con estroma linfoide adyacente (Fig. 1B). El diagnóstico histopatológico definitivo fue de adenoma pleomorfo y tumor de Warthin sincrónicos de parótida derecha.

\section{Caso 2}

Se trata de un varón de 77 años, que consulta por tumoración palpable preauricular izquierda de $3 \mathrm{~cm}$ de diámetro máximo, no dolorosa. Se realiza ecografía de la lesión que identifica, en glándula parótida izquierda, una lesión ocupante de espacio, hipoecógena, de $23 \times 12 \times 19 \mathrm{~mm}$ y de manera incidental, aprecia una lesión nodular hipoecógena que deja refuerzo posterior de $12 \times 9$ $\mathrm{mm}$ en glándula submaxilar izquierda.

Con estos datos se practica PAAF de ambos nódulos, observando en el de mayor tamaño abundante celularidad de talla grande, con núcleos centrales y ocasionalmente periféricos, redondeados, de nucleolo poco patente y cromatina finamente granular. El citoplasma es muy característico, siendo abundante, pálido y espumoso de bordes imprecisos, vacuolizado y conteniendo abundantes gránulos violáceos. Las células se disponen en grupos más o menos compactos de grandes láminas bidimensionales, adoptando en ocasiones un patrón arquitectural acinar. Junto con esta celularidad se aprecian células de talla más pequeña, con escaso citoplasma y pequeño núcleo redondeado u oval, central. La imagen citológica era acorde con tumor de células acinares, probablemente carcinoma por lo que se propuso extirpación.

La PAAF de la segunda lesión obtuvo menos material, dado su pequeño tamaño, no obstante se observó abundante celularidad homogénea, redondeada con citoplasma ligeramente basófilo y granular, de núcleo grande central, sin atipias. Se diagnosticó de sugestivo de oncocitoma, recomendando, también su exéresis.

El paciente no presenta alergias conocidas, es portador de marcapasos por BAV de $2^{\circ}$ grado, y sin otros datos de interés para el proceso actual, se ingresa de manera programada para intervención quirúrgica de tumoración parotídea izquierda y submaxilar izquierda.

El estudio histológico definitivo confirma la estirpe de ambos diagnósticos, asegurando al completa exéresis de ambas tumoraciones, así como la ausencia de infiltración de los márgenes quirúrgicos. Desgraciadamente no se conserva imagen macroscópica de estas piezas, se puede observar la microscopía en la Fig. 2.

\section{Discusión}

La existencia de tumores sincrónicos, de histología diferente, en glándulas salivares ipsilaterales o en una misma glándula es muy infrecuente. Suponen un $0,3 \%$ de todos los tumores de glándula salivar, siendo la asociación más frecuente la de tumor de Warthin imen was completely sectioned and it was routinely processed in order to obtain paraffin blocks. The stain used for the microscopical observation was the classical hematoxylineosin.

The microscopical study showed that the main tumor was well-circumscribed, and surrounded by a connective pseudo-capsule, composed of a biphasic population of glandular epithelial cells and myoepithelial cells that were surrounded by myxoid fibrillar material, and the diagnosis of pleomorphic adenoma was consequently confirmed. (Fig. 1C). The other nodules were lymphatic nodes, but a new lesion appeared, small in size, very close to the mixed tumor. It was cystic in appearance and papillary, and it was made up of a double strand of oncocytic cells that were lining the cystic spaces with the adjacent lymphoid stroma (Fig. 1B). The definitive histopathological diagnosis was of synchronous pleomorphic adenoma and Warthin's tumor of the right parotid gland.

\section{Case 2}

This was a 77 year-old male, that had a consultation for a palpable preauricular tumor-like mass on the left side, that was $3 \mathrm{~cm}$ in diameter and painless. An echography of the lesion was carried out which revealed a lesion that was occupying the space of the left parotid gland. It was hypoechogenic and measured $23 \times 12 \times 19 \mathrm{~mm}$. A nodular lesion was appreciated by chance that was hypoechogenic and which, with posterior enhancement, measured $12 \times 9 \mathrm{~mm}$ in the left submaxillary gland.

With this data FNA was carried out on both nodules. In the larger one the cellularity that was observed was greater and of a large size. The nuclei were in the center and occasionally at the periphery, and they were round with inconspicuous nucleoli and finely granular chromatin. The cytoplasm was very characteristic, being abundant, pale and foamy with indistinct borders. It was vacuolated and contained an abundance of purplish granules. The cells were arranged in groups that were more or less compact and in large bi-dimensional sheets, on occasions adopting an architectural pattern that was acinic. Next to this cellularity, smaller sized cells could be appreciated, with scant cytoplasm with small central nuclei either rounded or oval. The cytological image was consistent with a tumor made up of acinic cells, probably carcinoma and its excision was therefore proposed.

The FNA of the second lesion produced less material, given its smaller size. Nevertheless much homogenous cellular material was observed with rounded borders together with cytoplasm that was slightly basophilic and granular, with large central nuclei and no atypical features. This suggested a diagnosis of oncocytoma and its excision was also recommended.

The patient had no known allergies and he had a pacemaker due to $2^{\text {nd }}$ degree AVB. There was no other data of interest to the present case and he was admitted for programmed surgery for the tumor-like mass of the left parotid 
con otras entidades. ${ }^{1}$ En la bibliografía revisada hemos encontrado un total de 42 casos, de los que tan solo 9 se referían a la concurrencia de un tumor benigno y uno maligno -con mayor frecuencia Warthin y carcinoma mucoepidermoide- y 11 a la coexistencia de Warthin y adenoma pleomorfo. . $^{-4,6}$

Nuestros casos presentan la característica adicional de tener un diagnóstico inicial por PAAF de tres de las cuatro lesiones, siendo un hallazgo casual la cuarta lesión, es decir el tumor de Warthin del caso A. En nuestro centro se practica de manera rutinaria, a todos los pacientes con tumoración de probable origen salivar, una ecografía y PAAF empleando el método rutinario de 3 pases con aguja de 23G, y ayuda del Cameco $^{\circledR}$ (dispositivo de aspiración manual) tras lo cual se fijan en alcohol 2 portaobjetos para ser teñidos mediante la técnica de Papanicolaou y el resto (6 portas) se secan al aire para emplear la tinción de Diff-Quick. ${ }^{7}$

Gracias a este abordaje diagnóstico se pueden programar con mayor seguridad tanto las intervenciones quirúrgicas, como el seguimiento y control, en su caso, de los pacientes no susceptibles de cirugía. ${ }^{5}$

La mayor complejidad de los casos con doble tumor salivar estriba en instaurar un tratamiento eficaz para ambas lesiones, ya que dependiendo del tumor diagnosticado en primer lugar, y a veces en único, como en nuestro caso 1, pueden llevar a actitudes quirúrgicas insuficientes, obligando a reintervenir tras el
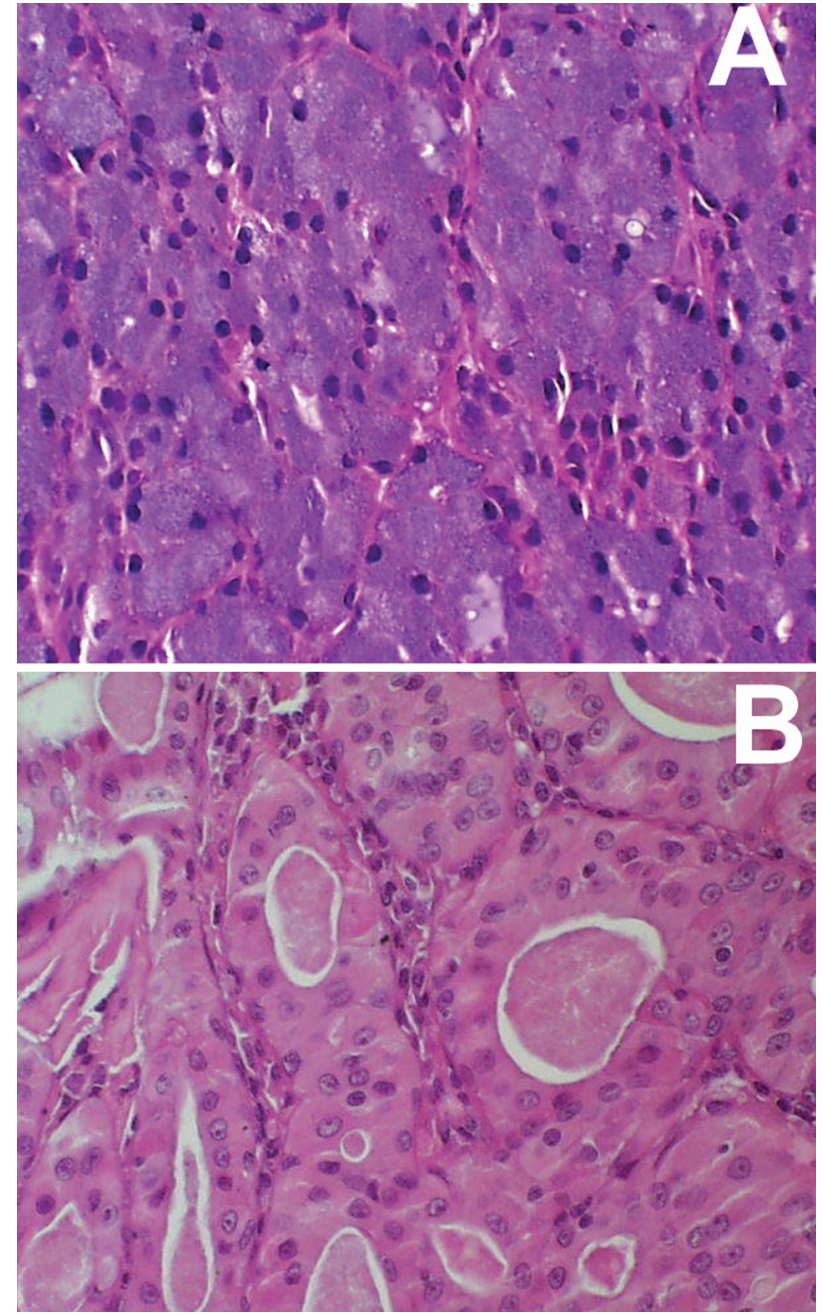

Figura 2. Microscopía óptica de corte histológico teñido con hematoxilina-eosina, magnificación original 40x, en la que se observa A) carcinoma de células acinares, B) proliferación de células oncocíticas constituyendo un oncocitoma.

Figure 2. Optical microscopy of histologic section stained with hematoxylin-eosin dye. Original magnification $\times 40$ showing A) acinic cell carcinoma, B) proliferation of oncocytic cells making up an oncocytoma. gland and left submaxillary gland.

The definitive histological examination confirmed the origin in both of the diagnoses, and the complete resection of both tumors, with no infiltration of the surgical margins. Unfortunately no macroscopic image has been kept of these specimens, but these can be seen microscopically in figure 2.

\section{Discussion}

The existence of synchronous tumors with different histological types in ipsilateral salivary glands or in the same gland is very rare. They account for $0.3 \%$ of all tumors of the salivary glands, and the most common association is a Warthin's tumor with other entities. ${ }^{1}$ In a revision of the literature we have found a total of 42 cases, of which 9 referred to the concurrence of a benign tumor with a malignant one - more frequently a Warthin's tumor with a mucoepidermoid carcinoma - and 11 to the coexistence of a Warthin's tumor with a pleomorphic adenoma. ${ }^{2-4,6}$

Our cases have the addiCon la aplicación rutinaria del estudio citológico se alcanzan altas cotas de efectividad, reduciendo el número de acciones diagnósticas más agresivas. No obstante el cirujano debe estar atento, y recordar, que aunque infrecuente, existen estos casos de doble lesión y por lo tanto ante cualquier nódulo mínimamente sospechoso en el acto quirúrgico se debe solicitar un estudio intraoperatorio. De hecho, algunos autores cuestionan la «infrecuencia» de estas lesiones y postulan la posibilidad de que, más que raros se trate de tumores no detectados. ${ }^{1}$

\section{Conclusiones}

Recomendamos un cuidadoso examen preoperatorio, incluyendo técnicas de imagen y PAAF para alcanzar un diagnóstico lo tional characteristic of having an initial diagnosis by FNA in three of the four lesions, with the fourth lesion being a casual finding, that is to say the Warthin's tumor in Case A. In our center an echography and FNA is routinely carried out on those patients with tumor-like masses with a likely salivary origin. Three passes are carried out with a $23 \mathrm{G}$ needle, with the help of a $\mathrm{Cameco}^{\circledR}$ (manual aspiration device) after which two slides are fixed in alcohol so that they can be stained with Papanicolaou's technique and the rest (6 slides) are air-dried so that the Diff-Quick stain can be used. ${ }^{7}$

Thanks to this diagnostic approach surgical interventions, as well as follow-ups and check-ups, as is the case, can be more reliably programmed for those patients not due for surgery. ${ }^{5}$

The most complicated part of cases with two salivary 
más ajustado posible, recordando la posibilidad de encontrar otros tumores incidentales en la misma glándula o adyacentes. En el acto quirúrgico se debe realizar un exhaustivo examen macroscópico, y ante cualquier sospecha, microscópico, para detectar tumores multifocales antes de cerrar el campo.

\section{Bibliografía}

1. Curry JL, Petruzzelli G], McClatchey KD, Lingen MW. Synchronous benign and malignant salivary gland tumors in ipsilateral glands: a report of two cases and a review of the literature. Head Neck 2002;24:301-6.

2. Zeebregts C], Mastboom W], van Noort G, van Det R). Synchronous tumours of the unilateral parotid gland: rare or undetected? / Craniomaxillofac Surg 2003;31:62-6.

3. Franzen A, Koegel K. Synchronous double tumors of the parotid gland. Laryngorhinootologie 1996;75:437-40.

4. Jonathan L. Curry, Guy J. Petruzzelli, Kenneth D. McClatchey, Mark W. Lingen. Synchronous benign and malignant salivary gland tumors in ipsilateral glands: A report of two cases and a review of literature. Head Neck 2002;24:301-6.

5. Azúa J. Citología por punción aspiración con aguja fina. Salvat Editores, 1987.

6. Ellis G, Auclair P. Malignant epithelial tumors. Rosai J, editor. Tumors of the Salivary Glands. Third series. Washington: AFIP, 1996;p.p.268-80.

7. J. Azúa Romeo, J. Azúa Blanco. Tricks for obtaining better material in FNA. Acta Cytologica 2001;45:664-5. tumors lies in establishing treatment that is efficient for both tumors as, depending on the tumor that has been diagnosed first, and sometimes there may be only one as in Case A, the surgical approach may be insufficient, and the patient may have to be reoperated following the definitive histopathological diagnosis. When cytological studies are routinely carried out, high levels of effectiveness are reached, and the number of more aggressive diagnostic procedures is reduced. Nevertheless the surgeon should be watchful, and he should remember that, although not very common, there are these cases of double lesions and when faced by a nodule that is minimally suspicious an intraoperative study should be requested. Many authors in fact question the «infrequency» of these lesions and postulate the possibility that, rather than rare, these are undetected tumors.?

\section{Conclusions}

We recommend a thorough preoperative examination, including imaging techniques and FNA in order to reach a diagnosis that is as accurate as possible, remembering that there can be a possibility of finding other tumor by chance in the same gland or an adjacent one. During the surgical act an exhaustive macroscopic examination should be carried out, and if there is anything suspicious, a microscopical examination should be carried out, in order to detect any multifocal tumors before closing the site. 